\title{
Determination of the Most Charismatic Leader Using Analytic Hierarchy Process and Fuzzy TOPSIS: An Application in Turkey
}

\author{
Derya Gul ${ }^{1}$, Ahmet Serhat Uludag ${ }^{2}$ \\ ${ }^{1}$ Department of Business, Faculty of Economics and Administrative Sciences, Ondokuz Mayıs University, Turkey \\ ${ }^{2}$ Department of International Trade and Logistics, Faculty of Economics and Administrative Sciences, Ondokuz Mayıs \\ University, Turkey \\ Correspondence: Ahmet Serhat Uludag, Department of International Trade and Logistics, Faculty of Economics and \\ Administrative Sciences, Ondokuz Mayis University, Samsun, Turkey. E-mail: serhat.uludag@omu.edu.tr
}

Received: April 21, 2016

Accepted: May 6, 2016

Online Published: May 23, 2016

doi:10.5539/ibr.v9n7p80

URL: http://dx.doi.org/10.5539/ibr.v9n7p80

\begin{abstract}
The concepts of leaders and leadership have been dealt with by many different disciplines, such as psychology and sociology, with the fields of management and political science being foremost, and have become frequent subject matter of academic discussions and research. The first studies in this field took place at the beginning of the $20^{\text {th }}$ century, with analysis of important personalities that changed the course of the history and shaped societies' futures with their extraordinary abilities and characteristics. It was predominantly these characteristics, as well as behavioral and situational approaches, that formed the basis of these first studies. The objective of this study is to determine which of the six presidents of the Republic of Turkey, who have served or are serving as Head of State, has more of the charismatic leadership characteristics, employing an interdisciplinary methodology in which multi-criteria decision-making methods and techniques are used. Within this context, the traits that a leader and a charismatic leader should have were determined, the weights of these traits were calculated using the Analytic Hierarchy Process (AHP), the calculated weights were used in the Fuzzy TOPSIS method, and the presidents were analyzed from the perspective of charismatic leadership. The results obtained support the predictions made before the study was begun. It was determined that Turgut Ozal, who was the $8^{\text {th }}$ President of Republic of Turkey, is the most charismatic leader among the selected presidents.
\end{abstract}

Keywords: analytic hierarchy process, charismatic leadership, fuzzy TOPSIS, leader, leadership, president

\section{Introduction}

From the past to the present, the concept of leadership has been of interest to many researchers from different disciplines, and has been a popular subject on which intensive research has been carried out (Lewin, 1944, McGregor, 1952, Bennis, 1959, Bennis and Nanus, 1985; Bass and Stogdill, 1990; Wren, 1995, Antonakis, 2006, Gill, 2011, Yukl, 2010). Researchers from different disciplines, such as anthropology (Bailey, 1988), sociology (Selznick, 1957), social psychology (Bass, 1985) and management (Zaleznik, 1989), have analyzed the concept from the perspective of their different fields (Rost, 1993). Researchers have analyzed the concept from the perspective of many different subjects, that inform political, social and cultural aspects of life, such as politics, the military, education, management, art, the media, social movements, movement of thought and religious topics (Sisman, 2014).

Humans are social beings and by their nature they need to communicate with other individuals, to love, to be loved, to be respected and to be a member of a group. This interaction between people causes, in time, the formation of groups that have similar characteristics, goals, objectives, ideals, lifestyles, beliefs and values. The formation of such groups leads to the question of how the common goals, objectives and ideals of the group can be attained. In fact, although what is talked about is a coming together of individuals who have similar features, it is an extremely difficult task to lead group members in the direction of attaining the group's common goals and objectives rather than their individual goals, to motivate them in this way, to keep them together and to manage them. At this juncture, individuals who have a more dominant character than other group members within a certain group, who can steer group members towards a common goal, who can motivate and mobilize group members, and who will be followed by group members, are needed. And this need is embodied in the concept of a leader. A leader is a person who affects others in a manner leading to action (Sabuncuoglu and Tuz, 2008). According to Ulgen and Mirze, however, a leader is "the person who determines the mission, basic goals and vision of an enterprise and who creates appropriate strategies" (Ulgen and Mirze, 2013). 
A literature review on the concept reveals that researchers have had a desire to give the concept of leadership a new perspective with respect to their own disciplines, and due to the different components taken into account by each researcher social scientists are unable to agree on a common definition to explain the concept (Eraslan, 2004); therefore there are too many different descriptions in the literature. Leadership, which is a multi-faceted concept, has been used widely throughout different periods of history to mean head of state, ruler, military commander and king (Stogdill and Bass, 1990). The fact that there is no agreed-upon definition for leadership leads to the necessity of analyzing previous definitions to explain the concept. According to Burns, leadership is the most frequently observed yet the least understood phenomenon in the world, and is "the reciprocal process of mobilizing by persons with certain motives and values, various economic, political and other resources, in a context of competition and conflict, in order to realize goals independently or mutually held by both leaders and followers" (Burns, 1978). According to another definition, leadership is the ability "to mobilize the structure with mutual behavior and agreement and continue with this situation" (Seters and Field, 1990). According to Yukl, leadership is "the process of identifying needs, understanding what should be done in what way, influencing others to reach an agreement, making individual and common works easier to attain predetermined targets" (Yukl, 2010). While Wren defines leadership as the "series of action and interaction processes between a leader and followers to reach common goals" (Wren, 1995), D. McGregor, who is known for his important studies in leadership, defines the concept as "a series of dynamic functional relationships between what must be done to satisfy organization members and organizational goals". According to McGregor, in the cases where organizational structures become too complex, establishing coordination between these said functional relationships leads to a need for a person defined as the leader. However, McGregor does not state this need as always inevitable; on the contrary, he states that it would be a futile effort to look for a leader type in an organization, or to look for the qualifications of an efficient leader, without taking into account the conditions of the organization and the needs of the organization's members (McGregor, 1952). In another study dealing with the concept, leadership is stated as a safe directing process of social activities, which would lead to disorder and chaos when not channeled in a certain direction; at the same time, leadership is an element which will provide higher satisfaction to a group in general and carry the group to a new situation, when it is exercised in a controlled manner (Murphy, 1941). While Kocel defines leadership as "a complex process which is made up of relationships between followers and conditions", Eren states that it is the "sum of knowledge and skills to bring together a group of people around certain goals and to mobilize them to realize these goals" (Eren, 2012). As can be understood from these definitions, leadership has generally been a concept explained by associating it with a leader's personal characteristics, qualities and behaviors (Horner, 1997, Yukl, 2010).

The objective of this study is to be able to associate management and quantitative methods, two quite different disciplines, with an interdisciplinary perspective, specifically for the concepts of leaders and leadership, subjects which never lose their popularity. Within this context, Kenan Evren, Turgut Ozal, Suleyman Demirel, Ahmet Necdet Sezer, Abdullah Gul and Recep Tayyip Erdogan, presidents of the Republic of Turkey, were analyzed from the perspective of charismatic leadership using multi-criteria decision-making (MCDM) methods. In a different manner from other studies that have been conducted to determine leadership types, the Analytic Hierarchy Process (AHP), Fuzzy TOPSIS as MCDM methods and techniques were used in this study. The qualities (criteria) that a leader and a charismatic leader should have were determined based on the literature, and the qualities and quantities of these criteria were given a final shape through interviews held with experts in the leadership topic in the fields of management and political science. The AHP was applied to determine the weights of the criteria. The weights obtained from this step were transferred to the Fuzzy TOPSIS method and the selected presidents were evaluated from the perspective of charismatic leadership, and the president with the highest score was determined.

Before moving to the implementation stage, a general assessment of the concepts of leadership and charismatic leadership is presented in the next section.

\section{Leadership and Charismatic Leadership}

A review of literature dealing with the concept shows that various approaches have been developed to analyze and to attempt to explain the concept of leadership. In some of these approaches leadership is accepted as a natal characteristic, while in others it is considered as a quality which can be gained and developed later on in life. One of the first studies on the traits that a leader has or should have was "The Great Man in History" by Thomas Carlyle (1840), who claimed that some people were born leaders (Lewin, 1944) and that they have influenced the history of mankind (Ercetin, 1998). The first systematic and scientific studies into leadership began at the beginning of the $20^{\text {th }}$ century with the analysis of "great men" who gave direction to societies and the course of history with their extraordinary abilities and characteristics. These studies and other studies following contributed to the development of the theory of personalities (Bass and Stogdill, 1990; Horner, 1997). In general, approaches which deal with the leadership concept that also involve the personalities approach are classified within a three-tier grouping as the personalities (1930-1940), behavior (1940 -1960) and contingency approaches (1960-1980) (Schoenfield, 1948, Sabuncuoglu and Tuz, 2008, Yukl, 2010, Kocel 2011, Eren, 2012). 
In this study, when heads of state were evaluated from the perspective of charismatic leadership, personalities and behavioral approaches from the above three approaches were taken into account. In other words, while an attempt was made to determine which of the six heads of state was the most charismatic leader, the evaluation was performed based on the personal characteristics of the leaders and the behaviors that these leaders exhibited towards their followers. To this end, the characteristics and behaviors exhibited by charismatic leaders were determined and the heads of state were analyzed from the point of view of charismatic leadership.

Charisma, is a concept that has led to wide and varied discussion among scientists. It was first used by Christian churches to qualify extraordinary behaviors by people of religious character as a gift from God (Weber, 1947; Tucker, 1968, Conger and Kanungo, 1994). In later periods, it gained religious, social and political meanings and was associated with certain power, authority and legitimacy types (Aslan, 2009, Kozleme, 2013). The concept is usually used with respect to the quality or qualities that make a person attractive, and people who are considered charismatic are thought to have superior characteristics (Demircioglu, 2015).

Weber, who tackles the concept from a sociological perspective, defines charisma as a power that helps an individual be distinguished from other people, and as an individual having superhuman, supernatural or extraordinary power and characteristics granted to him (Tucker, 1968). Weber's work provided the initiative for the development of new theories about charismatic leadership (Murphy, 1907, Bendix, 1967, Sashkin, 1988; Howell and Avolio: 1992, Conger and Kanungo, 1987; House, 1977; Burns, 1978; Katz and Kahn, 1978; Shamir et al., 1995). In these theories charismatic leadership was tackled within the contexts of the influence that a leader has over followers and leader-follower relationships (Yukl, 2010).

Previous research has shown that the probability of the emergence of a charismatic leadership style is usually higher when groups and organizations face conditions involving uncertainty, risk and stress. With their beliefs, qualities and unique behaviors, charismatic leaders are people who have a widespread, intensive social and charismatic effect on their followers. This effect emerges as a result of the leader's self-confident, dominant, extrovert personality, his/her strong beliefs, ethical values, unique behaviors, and the attitudes of followers, or a combination of these (Sosik, 2005).

Conger and Kanungo claim that charisma is an attributable phenomenon and, in their model, attempt to explain how charismatic leadership emerges within organizations. These researchers described charismatic leadership as an attribute based on followers' perception of their leader. In this model, charismatic leadership is dealt with as a three-stage process in which the first stage is an environmental assessment, the second stage is sharing or formulation of a vision, and the third stage is the implementation (Conger et al., 2000). In order to measure the model they developed, Conger and Kanungo later developed a measurement technique based on the determination and statement of a vision, the ability to take personal risks, sensitivity to the needs of followers, an exhibiting of extraordinary behaviors, not continuing with the status quo, and a sensitivity to environment (Conger and Kanungo, 1987; Rowold and Laukamp, 2008).

After the theoretical foundation presented so far about leaders, leadership and charismatic leadership, the following section elaborates on our evaluation of the six presidents who have served as Head of State of the Republic of Turkey from the perspective of charismatic leadership.

\section{Implementation: Assessment of Turkish Heads of State in the Context of Charismatic Leadership}

In this study, six presidents who served as Head of State for the Republic of Turkey were analyzed from the perspective of charismatic leadership style. Using a different approach from previous studies conducted on leadership and charismatic leadership, their leadership styles were assessed using a combination of the AHP and Fuzzy TOPSIS methods, used in solving MCDM problems. The qualities (criteria) that were used in the assessment of the presidents from the perspective of leadership were determined based on a search of the literature, and these criteria were given their final shape after interviews with field experts. The weights of the selected criteria were calculated using AHP and these weights were then transferred to the Fuzzy TOPSIS method, which allows for the use of qualitative data. In the final stage, using the Fuzzy TOPSIS method, the president who received the highest score with respect to charismatic leadership was determined. Figure 1 shows a simplified flow of the implementation. 


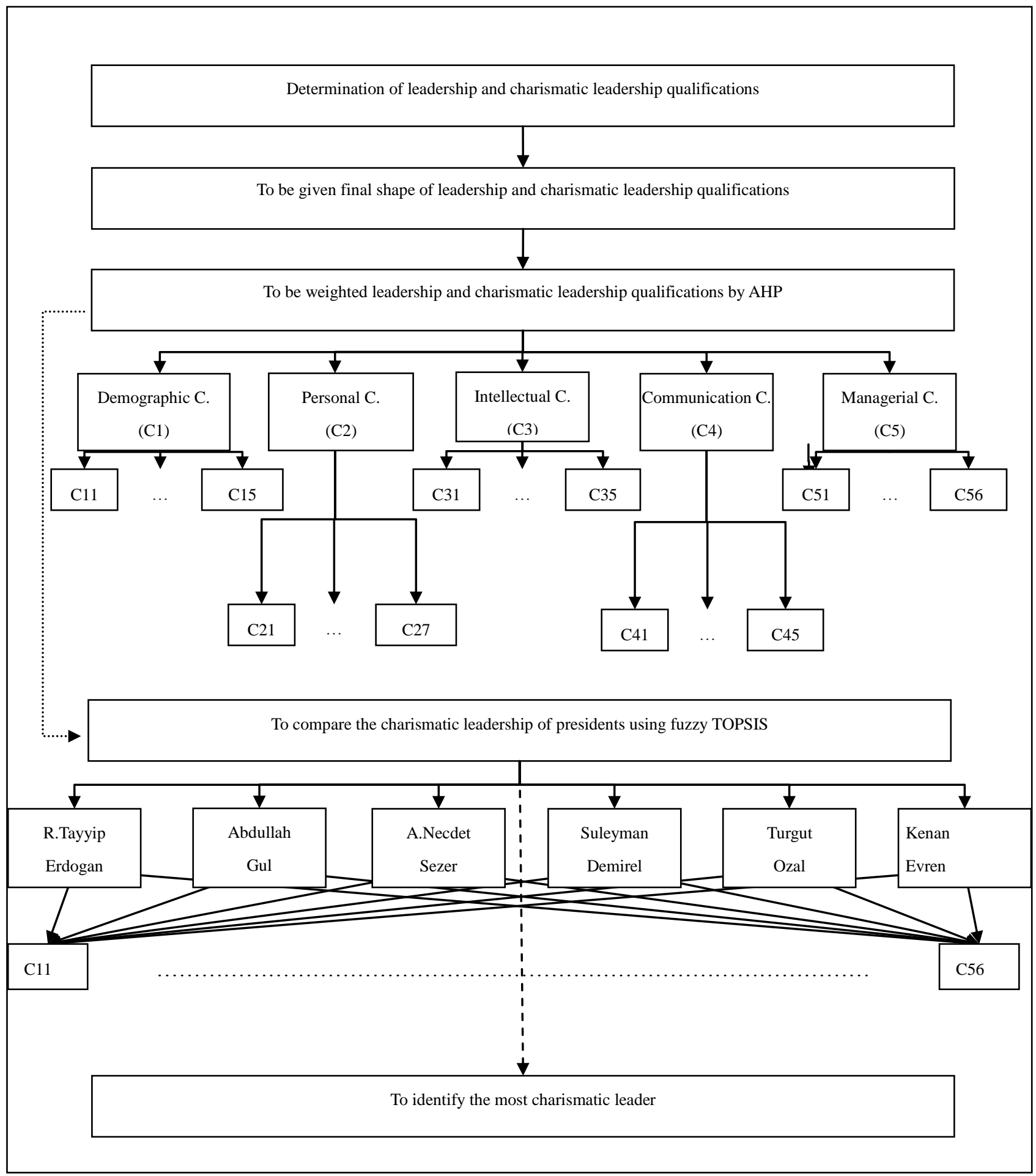

Figure 1. The phase of the most charismatic leader determination framework

Before moving to the implementation, the following section presents explanations in regards to the AHP and Fuzzy TOPSIS methods.

\subsection{Analytic Hierarchy Process}

The Analytic Hierarchy Process (AHP) is a method which was first proposed by T.L. Saaty in the 1970s for the solution of MCDM problems (Yildirim and Onder, 2015). The method provides an appropriate structure for the solution in cases where one or more decision makers must take more than one heuristic, rational or irrational criteria into account simultaneously, or in these types of problem structures (Saaty, 1986). Choosing the criteria to be used in the AHP is an important matter that requires creativity. After the criteria are determined, a hierarchical structure reflecting the 
relationship between main criteria, sub-criteria and alternatives is formed (Saaty, 1990). The AHP is an extremely easy to understand and use method for researchers, and does not require special software packages. That is why it can easily be applied even in very complex problems (Goksu and Gungor, 2008).

Because the AHP's scope of application is very extensive, the number of studies which have used this method is quite high. The method can be applied in many different fields, and has been used predominantly in the fields of supplier selection, distribution, supply chain and logistics ${ }^{1}$. Notwithstanding this, the number of studies in which the method is used in relation to leadership and charismatic leadership is very limited. In a study by Retchless et al. (2007), which is one of this limited number of studies, the AHP method was used to determine which of the selected seven American generals was the most successful. In the assessment of the generals two main criteria, ability and action, were used. While under the ability criteria conceptual, personal, tactical and technical sub-criteria were taken into account, under the action main criteria, participation in work, responsibility, success, and time interval sub-criteria were considered, making a total number of eight sub-criteria used in the AHP. Results obtained from the AHP showed that among the generals Omar Bradley, Dwight Eisenhower, Douglas MacArthur, George Marshall, George Patton, John Pershing and Matthew Ridgway, the most successful according to their analysis was George Marshall.

In another study dealing with the concept of leadership, Soylu et al. (2007) used the AHP to measure leadership components and the perceptions of mid-level managers working in the defense industry. In this study, the leader, the nature of the business, their subordinates, organizational structure, culture and time were considered components of the leadership function, and as a result of the AHP attention was drawn to the fact that in perceptions of leadership components "the leader" is an important factor. In another study Yilmaz (2010) examined how the AHP could be implemented in library and information science and attempted to explain how a library manager could be selected using this method.

The AHP's working process is shown below level by level (Saaty, 1986, Saaty, 1990, Saaty, 1994, Saaty, 2008, Saaty and Zoffer, 2012):

Level 1: Clearly putting forward the problem leaving no room for doubt.

Level 2: Determining and explaining main and sub-criteria.

Level 3: Determining alternatives or options, arranging a hierarchical structure that will associate main and sub-criteria with the options in most effective fashion.

Level 4: Determining a relative importance scale to construct a pair-wise comparison matrix

Table 1. Scale of Relative Importance

\begin{tabular}{|c|c|c|}
\hline $\begin{array}{l}\text { Importance } \\
\text { Degree }\end{array}$ & Description & Explanation \\
\hline 1 & Equally important & Both activities contributes equally to the aim \\
\hline 3 & Moderately important & Experience and judgment strongly favor one activity over another \\
\hline 5 & $\begin{array}{l}\text { Essential or strongly } \\
\text { important }\end{array}$ & Experience and judgment strongly favor one activity over another \\
\hline 7 & Very strongly important & An activity is strongly favored and its dominance demonstrated in practice \\
\hline 9 & $\begin{array}{l}\text { Extremely strongly } \\
\text { important }\end{array}$ & $\begin{array}{c}\text { The evidence favoring one activity over another is of the highest possible } \\
\text { order of affirmation }\end{array}$ \\
\hline $2,4,6,8$ & Intermediate values & When compromise is needed \\
\hline
\end{tabular}

(Saaty, 1990, Saaty, 1994)

Level 5: Constructing pair-wise comparison matrices that reflect the evaluation of participants. When "c" denotes the criteria, the pair wise comparison matrix for the " $m$ " criteria is as shown below:

$$
S=\left[c_{i j}\right]_{m x m^{\prime}}(i=1,2, \ldots, m \text { and } j=1,2, \ldots, m)
$$

Level 6: Calculating local and general weights of main and sub-criteria. (W) represents weights matrix where $c_{1}, c_{2}, \ldots$ $\mathrm{c}_{\mathrm{m}}$ are the criteria and $\mathrm{w}_{1}, \mathrm{w}_{2}, \ldots, \mathrm{w}_{\mathrm{m}}$ are the weights.

$$
W=\left[w_{i}\right]_{m x 1},(i=1,2, \ldots, m)
$$

\footnotetext{
${ }^{1}$ For the studies in which AHP has been used see: Lombardi et al. (2016) on renewable energy; Qu et al. (2015) on sea logistics; Kumru and Kumru (2014) on selection of transportation mode; Kapar (2013) on supplier selection; Tsita and Pilavachi (2012) on the transportation sector; Vidal et al. (2011) on project evaluation; Sarode and Sunnapwar (2010) on supplier selection; Erol et al. (2009) on sustainability in the retail sector; Atan et al. (2008) on human resource selection; Anand and Kodali (2007) on project evaluation; Erpolat and Cinemre (2006) on selection of business sector; Avaid and Marat (2005) on equipment selection.
} 
Level 7: Making consistency analysis for pair-wise comparison matrices. The consistency ratio (CR) of each pair-wise comparison matrix is calculated by dividing the consistency index (CI) value by the random index (RI) value. The RI values for different number criteria are shown in Table 2.

For consistency of pair-wise comparison matrices, in other words, to accept the inconsistency, it is suggested that the $\mathrm{CR}$ value not exceed $0.1(\mathrm{CR} \leq 0.1)$. On the other hand, the Consistency Index $(\mathrm{CI})$ value is calculated using equation (4). The $\lambda_{\max }$ coefficient in this equation is the greatest eigenvalue of pair-wise comparison matrices and calculated by the help of the formula shown in equation (5). In equation (5), (M) is the comparison matrix and " $\mathrm{b}$ " is the eigenvector.

$$
\begin{gathered}
\mathrm{CR}=\frac{\mathrm{CI}}{\mathrm{RI}} \\
\mathrm{CI}=\frac{\lambda_{\max }-\mathrm{m}}{\mathrm{m}-1} \\
M \cdot b=\lambda_{\max } \cdot \mathrm{b}
\end{gathered}
$$

Table 2. Random Value Index (RI)

\begin{tabular}{ccccccccccc}
\hline $\mathbf{n}$ & $\mathbf{1}$ & $\mathbf{2}$ & $\mathbf{3}$ & $\mathbf{4}$ & $\mathbf{5}$ & $\mathbf{6}$ & $\mathbf{7}$ & $\mathbf{8}$ & $\mathbf{9}$ & $\mathbf{1 0}$ \\
\hline $\mathbf{R I}$ & 0 & 0 & 0,52 & 0,89 & 1,11 & 1,25 & 1,35 & 1,41 & 1,45 & 1,49 \\
\hline
\end{tabular}

(Saaty, 1990)

Level 8: Calculating total priorities and performing ordering and selection tasks among the alternatives with respect to these priorities.

\subsection{Fuzzy TOPSIS}

The TOPSIS method was developed by Hwang and Yoon in 1981 for the solution of MCDM problems (Tayyar, 2012, p.356); the fuzzy logic method was developed by L.A. Zadeh as an alternative to Aristotle's dual logic, and gained reputation after it was published in Information and Control in 1965 (Trillas, 2011, p.576). Haven taken the interim values into account, fuzzy logic brought elasticity to the membership relationship, which is conceptualized as very rigid and unchanging in Aristotelian logic. To better illustrate this point, if we assume that the achievement criteria for the students who take a course is having a grade average of 90 at the end of term, and that students whose grade points are 90 constitute "the set of successful students", according to Aristotelian logic the only condition for a student to be member of the set in question is to have a grade point average of 90 at the end of term. Otherwise, the student is categorized as unsuccessful and cannot be accepted as a member of the set of successful students.

In regards to explaining membership relationship, Aristotelian logic, which takes into account the descriptions and/or values that are at extreme opposites to one another, such as "black-white", "good-bad", "slim-fat", "0-1" etc., became insufficient in solving real-life problems due to the "impossibility of third situation" principle, which is one of the three principles it is based on. In the context of the above example, according to Aristotelian logic, even if a student has grade point average of 89.9 at the end of term, he/she will not be accepted as a member of the group of successful students. In situations such as these fuzzy logic has provided the convenience to eliminate these types of deficiencies. Despite the fact that fuzzy logic also adopts lower and upper limits in the same way as Aristotelian logic, in regards to determining membership relationship, it is a logic type which does not neglect interim values but assigns different values to the membership relationship and accepts as a member of the set in question. Hence, unlike Aristotelian logic, according to fuzzy logic, a student who has an 89.9 end-of-term grade point average is not excluded from the set of successful students; rather with a qualification such as "quite successful" he/she is accepted as a member of the set.

Chen (2000) proposes the Fuzzy TOPSIS method, which provides a new approach for the solution of MCDM problems and which uses fuzzy logic together with the TOPSIS method, in which the use of quantitative and comparable data is mandatory. Although fuzzy logic makes relatively simple and understandable mathematical operations under the TOPSIS method a bit more complex, its fundamental logic is similar to the TOPSIS method. The difference between the two is that fuzzy logic requires special mathematical calculations, and for evaluations and judgments about criteria and alternatives decision makers uses language statements that correspond to different fuzzy numbers.

There are many studies in the literature about the use of the fuzzy TOPSIS method in different fields ${ }^{2}$. In these and other

${ }^{2}$ For some studies in which fuzzy TOPSIS is used see: Ardakani et al. (2015) on service quality; Kabra and Ramesh (2015) on human supply chain management; Mahdevari et al. (2014) on the health and safety of coal miners; Sari (2013) on RFID solution provider selection; Uysal and Tosun (2012) on software selection; Eraslan and Tansel (2011) on determination of investment regions; Erginel et al. (2010) on determining market shares of GSM operators; Gokdalay and 
studies in the literature it is observed that in order to digitize language statements, mostly triangular and trapezoid fuzzy numbers are selected. In this study it was decided to use triangular fuzzy numbers. Some of the basic features and the solution process of the Fuzzy TOPSIS method are presented below.

A graphical representation of a triangular fuzzy number in the form of $\tilde{t}=\left(t_{l}, t_{m}, t_{u},\right)$ is as follows (Ecer, 2006).

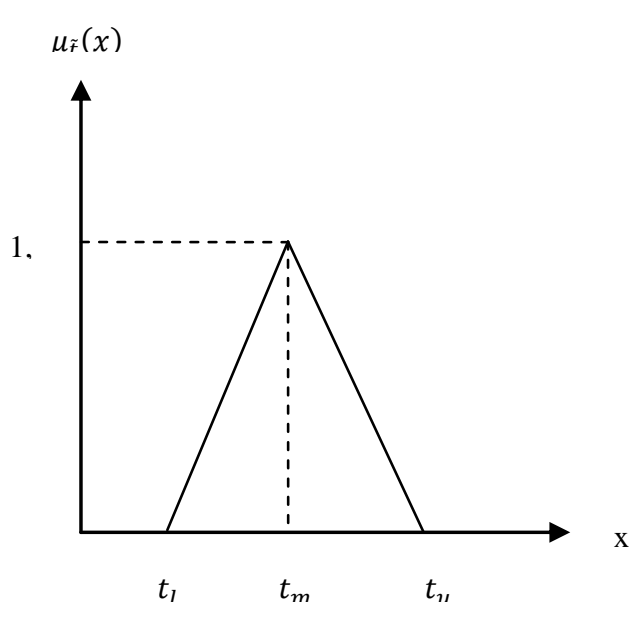

The membership function of a triangular fuzzy number in the form of $\tilde{t}=\left(t_{l}, t_{m}, t_{u}\right)$ is as follows:

$$
\mu_{\tilde{t}}(x)=\left\{\begin{array}{lr}
0, & x<t_{l}, \\
\frac{x-t_{l}}{t_{m}-t_{l}}, & t_{l} \leq x \leq t_{m} \\
\frac{x-t_{u}}{t_{m}-t_{u}}, & t_{m} \leq x \leq t_{u} \\
0, & x>t_{u}
\end{array}\right\}
$$

Figure 2. Triangular Fuzzy Number

When $\tilde{t}=\left(t_{l}, t_{m}, t_{u},\right)$ and $\tilde{z}=\left(z_{l}, z_{m}, z_{u},\right)$ are two positive fuzzy numbers, and $\mathrm{s}$ is a positive real number, some basic mathematical operations between two fuzzy numbers are as shown below:

$\tilde{t} \oplus \tilde{z}=\left[t_{l}+z_{l}, t_{u}+z_{u}\right]$

$\tilde{t} \Theta \tilde{z}=\left[t_{l}-z_{u}, t_{u}-z_{l}\right]$

$\tilde{t} \otimes \tilde{z}=\left[t_{l}, z_{l}, t_{u} \cdot z_{u}\right]$

$\tilde{t} \otimes s=\left[t_{l} . s, t_{u} \cdot s\right]$

After the basic mathematical operations in fuzzy numbers, the solution process of the Fuzzy TOPSIS method is shown below (Chen, 2000: 5-6):

Level 1: Constructing initial fuzzy decision matrix $(\widetilde{T})$ and fuzzy weights matrix $(\tilde{A})$.

In a decision makers group which consists of " $U$ " experts,

$\tilde{a}_{j}^{u}$ : importance weight of $\mathrm{j}^{\text {th }}$ criterion with respect to $\mathrm{u}^{\text {th }}$ specialist

$\tilde{b}_{i j}^{u}: \mathrm{j}^{\text {th }}$ criterion value of $\mathrm{i}^{\text {th }}$ alternative with respect to $\mathrm{u}^{\text {th }}$ specialist

$$
\begin{gathered}
\text { If } i=1,2, \ldots, x ; j=1,2, \ldots, y \text { and } \tilde{b}_{i j}=\left(d_{i j}, e_{i j}, f_{i j}\right), \quad \tilde{a}_{j}=\left(a_{j 1}, a_{j 2}, a_{j 3}\right) ; \\
\tilde{T}=\left[b_{i j}\right]_{x * y} \\
\tilde{A}=\left[a_{j}\right]_{1 * y}
\end{gathered}
$$

Level 2: Calculating normalized fuzzy values $\left(\tilde{n}_{i j}\right)$ and constructing a normalized fuzzy decision matrix $(\widetilde{N})$.

If $i=1,2, \ldots, x$ and $j=1,2, \ldots, y$;

$$
\widetilde{N}=\left[\tilde{n}_{i j}\right]_{x * y}
$$

Level 3: Calculating weighted normalized fuzzy values $\left(\tilde{g}_{i j}\right)$ and constructing a weighted normalized fuzzy decision matrix $(\tilde{G})$.

$$
\begin{aligned}
\tilde{G} & =\left[\tilde{g}_{i j}\right]_{x * y} \\
\tilde{g}_{i j} & =\tilde{n}_{i j} \cdot a_{j}
\end{aligned}
$$

Evren (2009) on the evaluation of performance of airports; Sun and Lin (2009) on assessment of competitive advantage of web-based shopping sites; Onut and Soner (2008) on enterprise location selection; Kahraman et al. (2007) on logistics information technologies selection; Yong (2006) on plant location selection. 
Level 4: Determining fuzzy positive ideal solution values $\left(I^{+}\right)$and fuzzy negative ideal solution values $\left(I^{-}\right)$for each alternative.

If $i=1,2, \ldots, x$ and $j=1,2, \ldots, y$;

$$
\begin{aligned}
& I^{+}=\left(\tilde{g}_{1}^{+}, \tilde{g}_{2}^{+}, \ldots, \tilde{g}_{j}^{+}\right) \\
& I^{-}=\left(\tilde{g}_{1}^{-}, \tilde{g}_{2}^{-}, \ldots, \tilde{g}_{j}^{-}\right)
\end{aligned}
$$

Level 5: Determining the distance of each alternative from $\left(h_{i}^{+}\right)$and $\left(h_{i}^{-}\right)$.

If $i=1,2, \ldots, x$ and $j=1,2, \ldots, y$;

$$
\begin{aligned}
& h_{i}^{+}=\sum_{j=1}^{y} h\left(\tilde{g}_{i j}, \tilde{g}_{j}^{+}\right) \\
& h_{i}^{-}=\sum_{j=1}^{y} h\left(\tilde{g}_{i j}, \tilde{g}_{j}^{-}\right) \\
& \tilde{g}_{j}^{+}=\underbrace{\max }_{i} \tilde{g}_{i j} \\
& \tilde{g}_{j}^{+}=\underbrace{\min }_{i} \tilde{g}_{i j}
\end{aligned}
$$

Level 6: Determining closeness degrees $\left(C D_{i}\right)$.

$$
C D_{i}=\frac{h_{i}^{-}}{h_{i}^{+}+h_{i}^{-}}
$$

\subsection{Determining the Criteria and Calculating Criteria Weights Using the AHP Method}

At this stage, first, face-to-face interviews were conducted with field experts, and leadership criteria (qualities) derived from the literature (Can et al., 2006, Kocel, 2011, Ertan and Kantos, 2011, Conger and Kanungo 1998, Arklan, 2006, Unal and Ibicioglu, 2014, Yilmaz, 2010) were given a final shape from quantitative and qualitative perspectives. In this context, the six presidents who served and have been serving in the Republic of Turkey between 1982-2015 (Recep Tayyip Erdogan (A1), Abdullah Gul (A2), A. Necdet Sezer (A3), Suleyman Demirel (A4), Turgut Ozal (A5), Kenan Evren (A6)) were evaluated from the perspective of charismatic leadership using the main and sub decision criteria presented below:

- (C1) Demographic Criteria [age (C11), gender (C12), marital status (C13), educational status (C14), physical appearance (C15)]

- (C2) Personal criteria [being reliable (C21), taking risks (C22), stability (C23), self-confidence (C24), to take lessons from mistakes (C25), to drag the vast masses of people (C26), to cope with stress (C27)]

- (C3) Mental Criteria [intelligence (C31), creativity (C32), analytical thinking (C33), discernment (C34), cultural consciousness (C35)]

- (C4) Communication Criteria [ability to persuade (C41), the expression capability (C42), to be able to empathise (C43), effective communication (C44), to use appropriate language consonant with social structure (C45)]

- (C5) Administrative Criteria [service-oriented or not (C51), determination and expression of vision (C52), sensitivity to needs of followers (C53), not continuing with status quo (C54), aptitude for teamwork (C55), support the professional development of employees (C56)]

Having determined the decision criteria and decision points, the decision criteria were evaluated by decision makers using the importance scale previously shown in Table 1. In this way the pair-wise comparison matrices shown in tabular format below were obtained. 
Table 3. Pair-wise Comparison Matrix for Main Criteria

\begin{tabular}{cccccc}
\hline Main Criteria & C1 & C2 & C3 & C4 & C5 \\
\hline C1 & 1 & $1 / 5$ & $1 / 7$ & $1 / 7$ & $1 / 4$ \\
C2 & 5 & 1 & $1 / 3$ & $1 / 3$ & $1 / 3$ \\
C3 & 7 & 3 & 1 & 1 & 1 \\
C4 & 7 & 4 & 3 & 1 & 1 \\
\hline
\end{tabular}

Table 4. Pair-wise Comparison Matrix for Demographic Criteria

\begin{tabular}{cccccc}
\hline Demographic Criteria & C11 & C12 & C13 & C14 & C15 \\
\hline C11 & 1 & 3 & 3 & $1 / 7$ & 1 \\
C12 & $1 / 3$ & 1 & $1 / 3$ & $1 / 5$ & 1 \\
C13 & $1 / 3$ & 3 & 1 & $1 / 7$ & 1 \\
C14 & 7 & 5 & 7 & 7 & $1 / 7$ \\
\hline
\end{tabular}

Table 5. Pair-wise Comparison Matrix for Personal Criteria

\begin{tabular}{cccccccc}
\hline Personal Criteria & C21 & C22 & C23 & C24 & C25 & C26 & C27 \\
\hline C21 & 1 & 3 & 1 & 3 & 1 & 1 & 3 \\
C22 & $1 / 3$ & 1 & $1 / 3$ & $1 / 3$ & $1 / 3$ & 1 & 1 \\
C23 & 1 & 3 & 1 & 1 & $1 / 3$ & 3 & 1 \\
C24 & $1 / 3$ & 3 & 1 & 1 & 1 & 1 & 3 \\
C25 & 1 & 3 & 3 & 1 & 1 & 1 & 1 \\
C26 & 1 & 1 & $1 / 3$ & 1 & 1 & 1 \\
C27 & $1 / 3$ & 1 & 1 & $1 / 3$ & $1 / 3$ & 1 \\
\hline
\end{tabular}

Table 6. Pair-wise Comparison Matrix for Mental Criteria

\begin{tabular}{|c|c|c|c|c|c|}
\hline Mental Criteria & C31 & C32 & C33 & C34 & C35 \\
\hline C31 & 1 & 1 & $1 / 3$ & $1 / 3$ & 1 \\
\hline $\mathbf{C 3 2}$ & 1 & 1 & 1 & 1 & 3 \\
\hline $\mathbf{C 3 3}$ & 3 & 1 & 1 & 1 & 5 \\
\hline C34 & 3 & 1 & 1 & 1 & 3 \\
\hline C35 & 1 & $1 / 3$ & 0,2 & $1 / 3$ & 1 \\
\hline
\end{tabular}

Table 7. Pair-wise Comparison Matrix for Communication Criteria

\begin{tabular}{cccccc}
\hline Communication Criteria & C41 & $\mathbf{C 4 2}$ & $\mathbf{C 4 3}$ & $\mathbf{C 4 4}$ & $\mathbf{C 4 5}$ \\
\hline $\mathbf{C 4 1}$ & 1 & $1 / 3$ & $1 / 3$ & $1 / 3$ & $1 / 3$ \\
$\mathbf{C 4 2}$ & 3 & 1 & 1 & 1 \\
$\mathbf{C 4 3}$ & 3 & 1 & 1 & 1 & 1 \\
$\mathbf{C 4 4}$ & 3 & 3 & 1 & 1 & 1 \\
$\mathbf{C 4 5}$ & 3 & 1 & 1 & 1 \\
\hline
\end{tabular}

Table 8. Pair-wise Comparison Matrix for Administrative Criteria

\begin{tabular}{ccccccc}
\hline Administrative Criteria & C51 & C52 & C53 & C54 & C55 & C56 \\
\hline C51 & 1 & 1 & $1 / 3$ & 3 & 1 & $1 / 3$ \\
C52 & 1 & 1 & 1 & 3 & 1 & 1 \\
C53 & 3 & 1 & 1 & 5 & 5 & 1 \\
C54 & $1 / 3$ & $1 / 3$ & $1 / 5$ & 1 & 1 & $1 / 5$ \\
C55 & 1 & 1 & $1 / 5$ & 1 & 1 & $1 / 3$ \\
C56 & 3 & 1 & 1 & 5 & 3 & 1 \\
\hline
\end{tabular}

After constructing pair-wise comparison matrices, the operations described in Levels 6, 7 and 8, explained in the section above where the AHP solution process is elaborated, were performed, and the weights and consistency ratios of main and sub criteria were calculated. Weights of the main criteria and consistency ratio of the pair-wise comparison matrix which was constructed for the main criteria are shown in Table 9, and local and general weights of sub criteria, as well as the consistency ratios of the pair-wise comparison matrices for the sub criteria, are shown in Table 10.

Table 9. Main Criteria Weights and Contingency of Pair-wise Comparison Matrix

\begin{tabular}{ccc}
\hline Main Criteria & Weights & $\boldsymbol{\lambda}$ max, CI, RI ve CR \\
\hline Demographic Criteria & 0,035 & $\Lambda$ mak $=5,278$ \\
Personal Criteria & 0,105 & $\mathrm{CI}=0,0695$ \\
Mental Criteria & 0,180 & $\mathrm{RI}=1,12$ \\
Communicatin Criteria & 0,330 & $\mathrm{CR}=0,062$ \\
Administrative Criteria & 0,348 & \\
\hline
\end{tabular}


According to Table 9 the most important factors that determine charismatic leadership are the communication main criteria, with a weight of 0.348 . The communication criteria are followed by managerial criteria with 0.330 , mental criteria with 0.180 , personal criteria with 0.105 and finally demographic criteria with 0.035 . As can be inferred from Table 9 the consistency index (CI) of the pair-wise comparison matrix that was constructed for the main criteria was calculated as 0.0695; the random index (RI) for five criteria was 1.12 and the consistency ratio (CR) was calculated as 0.062 . That consistency ratio turned out to be less than 0.1 , showing that inconsistency is at an acceptable level.

After the calculation of the weights of the main criteria, the weights of the sub-criteria and the consistency ratios of the pair-wise comparison matrices constructed for the main criteria were also calculated. These calculated values are collectively shown in Table 10.

Table 10. Main and Sub-criteria Weights and Contingencies of Pair-wise Comparison Matrices

\begin{tabular}{|c|c|c|c|c|c|}
\hline Main Criteria & Sub-criteria & $\begin{array}{l}\text { General } \\
\text { Weights }\end{array}$ & Local Weights & $\begin{array}{c}\lambda \max \\
\text { CI ve RI }\end{array}$ & $\mathbf{C R}$ \\
\hline \multirow{5}{*}{ 产 } & Age & 0,005 & 0,151 & \multirow{5}{*}{$\begin{array}{c}\lambda \max =5,449 \\
\mathrm{CI}=0,112 \\
\mathrm{RI}=1,12\end{array}$} & \multirow{5}{*}{0,10} \\
\hline & Gender & 0,002 & 0,070 & & \\
\hline & Marital status & 0,003 & 0,104 & & \\
\hline & Educational status & 0,020 & 0,585 & & \\
\hline & Physical appearance & 0,003 & 0,088 & & \\
\hline \multirow{7}{*}{ 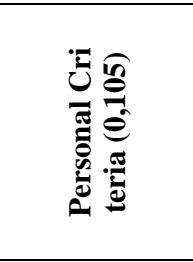 } & Being reliable & 0,022 & 0,209 & \multirow{7}{*}{$\begin{array}{c}\lambda \max =7,623 \\
\mathrm{CI}=0,103 \\
\mathrm{RI}=1,32\end{array}$} & \multirow{7}{*}{0,078} \\
\hline & Taking risk & 0,007 & 0,068 & & \\
\hline & Stability & 0,017 & 0,162 & & \\
\hline & Self-confidence & 0,016 & 0,152 & & \\
\hline & To take lessons from mistakes & 0,022 & 0,209 & & \\
\hline & To drag the vast masses of people & 0,012 & 0,118 & & \\
\hline & To cope with stress & 0,008 & 0,080 & & \\
\hline \multirow{5}{*}{ 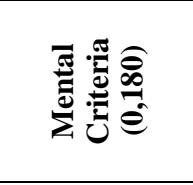 } & Intelligence & 0,022 & 0,122 & \multirow{5}{*}{$\begin{array}{c}\lambda \max =5,191 \\
\mathrm{CI}=0,047 \\
\mathrm{RI}=1,12\end{array}$} & \multirow{5}{*}{0,042} \\
\hline & Creativity & 0,040 & 0,225 & & \\
\hline & Analytical thinking & 0,053 & 0,298 & & \\
\hline & Discernment & 0,048 & 0,270 & & \\
\hline & Cultural consciousness & 0,014 & 0,082 & & \\
\hline \multirow{5}{*}{ 已゙ } & Ability to persuade & 0,026 & 0,074 & \multirow{5}{*}{$\begin{array}{c}\lambda \max =5,150 \\
\mathrm{CI}=0,037 \\
\mathrm{RI}=1,12\end{array}$} & \multirow{5}{*}{0,033} \\
\hline & The expression capability & 0,065 & 0,188 & & \\
\hline & To be able to empathise & 0,078 & 0,224 & & \\
\hline & Effective communication & 0,100 & 0,287 & & \\
\hline & To use appropriate language consonant with social structure & 0,078 & 0,224 & & \\
\hline \multirow{6}{*}{ 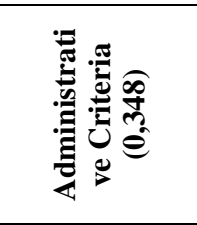 } & Service-oriented or not & 0,039 & 0,120 & \multirow{6}{*}{$\begin{array}{c}\lambda \max =6,306 \\
\mathrm{CI}=0,061 \\
\mathrm{RI}=1,24\end{array}$} & \multirow{6}{*}{0,049} \\
\hline & Determination and expression of vision & 0,058 & 0,178 & & \\
\hline & Sensitivity to needs of followers & 0,095 & 0,288 & & \\
\hline & Not continuing with the status quo & 0,018 & 0,057 & & \\
\hline & Aptitude for teamwork & 0,031 & 0,095 & & \\
\hline & To support the professional development of employees & 0,086 & 0,260 & & \\
\hline
\end{tabular}

According to Table 10, while from among the sub-criteria the most important criterion that affects charismatic leadership is "effective communication", with a general weight of 0.100 , the least importance was attributed to the gender criterion, with a general weight of 0.002 . From the demographic criteria, "educational status", with a general weight of 0.020 , was determined to be the most effective in charismatic leadership, and gender with a weight of 0.002 was determined to be the least effective. From among personal criteria, "being reliable", with a general weight of 0.022 , was the most effective criteria in charismatic leadership, while "taking risks" was the least effective. From among mental criteria, "analytical thinking" with a weight of 0.053, ranked first from the perspective of charismatic leadership, while "cultural consciousness", with a general weight of 0.014 ranked last. From communication criteria, "effective communication", with a general weight of 0.100 is the sub-criteria that has the highest effect, while "ability to persuade" with a weight of 0.026 was the least effective sub-criteria within the communication main criteria. Finally, from the managerial criteria, "sensitivity to needs of followers" with a general weight of 0.095 , was determined as the most effective sub-criteria, while "not continuing with the status quo", with a weight of 0.018 was the least effective sub-criteria.

As can be clearly observed in Table 10, our calculations showed that the consistency ratios of the pair-wise comparison matrices, which were constructed for each sub-criteria, are equal to or less than 0.1 . Therefore it was accepted that the inconsistency for all comparison matrices is at an acceptable level. In order to better see the weights and importance degrees of the sub-criteria, the sub-criteria are ordered with respect to general weights in 
Table 11. Weights and Raking of Sub-criteria

\begin{tabular}{|c|c|c|c|c|c|}
\hline Ranking & Sub-criteria & Weights & Ranking & Sub-criteria & Weights \\
\hline 1 & Effective communication & 0,100 & 15 & $\begin{array}{l}\text { To take lessons from } \\
\text { mistake }\end{array}$ & 0,022 \\
\hline 2 & Sensitivity to needs of followers & 0,095 & 16 & Intelligence & 0,022 \\
\hline 3 & $\begin{array}{c}\text { To support the professional development of } \\
\text { employees }\end{array}$ & 0,086 & 17 & Educational status & 0,020 \\
\hline 4 & To be able to empathise & 0,078 & 18 & $\begin{array}{l}\text { Not continuing with the } \\
\text { status quo }\end{array}$ & 0,018 \\
\hline 5 & $\begin{array}{l}\text { To use appropriate language consonant } \\
\text { with social structure }\end{array}$ & 0,078 & 19 & Stability & 0,017 \\
\hline 6 & The expression capability & 0,065 & 20 & Self-confidence & 0,016 \\
\hline 7 & Determination and expression of vision & 0,058 & 21 & Cultural consciousness & 0,014 \\
\hline 8 & Analytical thinking & 0,053 & 22 & $\begin{array}{l}\text { To drag the vast masses of } \\
\text { people }\end{array}$ & 0,012 \\
\hline 9 & Discernment & 0,048 & 23 & To cope with stress & 0,008 \\
\hline 10 & Creativity & 0,040 & 24 & Taking risks & 0,007 \\
\hline 11 & To be service-oriented & 0,039 & 25 & Age & 0,005 \\
\hline 12 & Aptitude for teamwork & 0,031 & 26 & Marital status & 0,003 \\
\hline 13 & Ability to persuade & 0,026 & 27 & Physical appearance & 0,003 \\
\hline 14 & Being reliable & 0,022 & 28 & Gender & 0,002 \\
\hline
\end{tabular}

3.4 Evaluation of Presidents from the Perspective of Charismatic Leadership Using the Fuzzy TOPSIS Method

At this stage of the implementation the six presidents, previously stated as decision points or alternatives, were evaluated from the perspective of charismatic leadership using the Fuzzy TOPSIS method. Table 12 presents the decision points and brief information about these decision points.

Table 12. Decision Points and Brief Information about these Decision Points

Presidents (Decision Points)

Recep Tayyip Erdogan, who is the 12th President of State of the Republic of Turkey, was born in 1954 in Istanbul. Erdogan,

A1 who worked as mayor between 1994 and 1998, and served 11 years between 2003 and 2014 as Prime Minister, took office in 2014 as the first president to be directly elected by public voting.

Abdullah Gul, who was the 11th President of State of the Republic of Turkey, was born in 1950 in Kayseri. Gul served as

A2 Prime Minister in 2002, and as Deputy Prime Minister and Minister of Foreign Affairs during the period of the 59th Government. Abdullah Gul was president in the period 2007-2014.

A3 Ahmet Necdet Sezer was the 10th President of State of the Republic of Turkey, and was born in Afyonkarahisar in 1941. Sezer, who was also 15th President of the Constitutional Court, served as president between 2000 and 2007.

Suleyman Demirel, who was the 9th President of State of the Republic of Turkey, was born in Isparta in 1924. He worked as

A4 party leader in various parties in the period 1964-1980. Between 1965 and 1993 Suleyman Demirel served as Prime Minister in seven different governments for 10 years and 5 month. He was president between 1993 and 2000.

Turgut Ozal was the 8th President of State of the Republic of Turkey, and was born in Malatya in 1927. Ozal, who came to

A5 power in 1983 at the head of a single party government with the party he founded, served as Prime Minister of the 45th Government and as president between 1989 and 1993.

Kenan Evren was the 7th President of State of the Republic of Turkey, and was born in Manisa in 1917. He was the 17th A6 Chief of General Staff of the Turkish Armed Forces and he assumed the position of head of state after the 12th September 1980 military coup. Evren served as president between 1982 and 1989.

(http://www.tccb.gov.tr/cumhurbaskanlarimiz/)

It is a requirement of the Fuzzy TOPSIS method that a decision-making group composed of experts should be formed. To this end, a group composed of academics who have worked on the subject of leadership was established. These decision makers were asked to evaluate the presidents shown in Table 12 using previously determined charismatic leadership qualities. The linguistic statements that the decision makers used during their evaluation and the triangular fuzzy numbers corresponding to these statements are presented in Table 13.

Table 13. Linguistics Statements and Tringular Fuzzy Numbers

\begin{tabular}{ccccc}
\hline Linguistics Statements & \multicolumn{3}{c}{ Tringular Fuzzy Numbers } \\
\hline Very Good & 9 & 10 & 10 \\
Good & 7 & 9 & 10 \\
Medium Good & 5 & 7 & 9 \\
Fair & 3 & 5 & 7 \\
Medium Poor & 1 & 3 & 3 \\
Poor & 0 & 1 & 0 \\
\hline
\end{tabular}

(Chen, 2000)

After this stage, the initial fuzzy decision matrix $(\tilde{T})$, which was given a place in Level 1 in the section where the solution process for the Fuzzy TOPSIS method is explained, should be constructed together with the weights matrix $(\tilde{A})$. 
The initial fuzzy decision matrix that was constructed based on the evaluations of the decision makers is presented in Table 14. Criteria weights used in the Fuzzy TOPSIS method were previously calculated using the AHP. Because these calculated weights are shown already in Table 11, the weights matrix has not been given space here again. Having constructed the initial fuzzy decision and weights matrices, Level 2 was initiated.

Table 14. The Preliminary Fuzzy Decision Matrix

\begin{tabular}{|c|c|c|c|c|c|c|c|c|c|}
\hline & \multicolumn{3}{|c|}{$\mathrm{A}_{1}$} & \multicolumn{3}{|c|}{$\mathrm{A}_{2}$} & \multicolumn{3}{|c|}{$\mathrm{A}_{3}$} \\
\hline & $t_{1}$ & $\mathrm{t}_{\mathrm{m}}$ & $\mathrm{t}_{\mathrm{u}}$ & $\mathrm{t}_{1}$ & $\mathrm{t}_{\mathrm{m}}$ & $\mathrm{t}_{\mathrm{u}}$ & $\mathrm{t}_{\mathrm{l}}$ & $\mathrm{t}_{\mathrm{m}}$ & $\mathrm{t}_{\mathrm{u}}$ \\
\hline C11 & 7,67 & 9,33 & 10 & 7 & 8,67 & 9,67 & 5,67 & 7,33 & 8,67 \\
\hline $\mathrm{C} 12$ & 7 & 9 & 10 & 7 & 9 & 10 & 7 & 9 & 10 \\
\hline $\mathrm{C} 13$ & 7 & 9 & 10 & 7 & 9 & 10 & 7 & 9 & 10 \\
\hline C14 & 3,67 & 5,67 & 7,67 & 7 & 8,67 & 9,67 & 6,33 & 8,33 & 9,67 \\
\hline C15 & 5,67 & 7,67 & 9 & 7 & 8,67 & 9,67 & 5,67 & 7,67 & 9,33 \\
\hline C21 & 2,67 & 4,33 & 6 & 4,67 & 6,33 & 7,67 & 2,67 & 4,33 & 6,33 \\
\hline C22 & 7 & 8,33 & 9 & 2 & 3,67 & 5,67 & 3,33 & 5 & 6,67 \\
\hline $\mathrm{C} 23$ & 6,33 & 8 & 9 & 4 & 5,67 & 7,33 & 3,67 & 5,67 & 7,33 \\
\hline C24 & 8,33 & 9,67 & 10 & 3,67 & 5,67 & 7,33 & 4,33 & 6,33 & 8 \\
\hline C25 & 1 & 2,33 & 4,33 & 2,67 & 4,33 & 6,33 & 1 & 2,33 & 4,33 \\
\hline C26 & 7 & 9 & 10 & 2,67 & 4,33 & 6,33 & 1,33 & 3 & 5 \\
\hline C27 & 6,33 & 8,33 & 9,67 & 3 & 5 & 7 & 3,67 & 5,67 & 7,33 \\
\hline C31 & 5 & 7 & 8,67 & 4 & 5,67 & 7,33 & 1,67 & 3,67 & 5,67 \\
\hline C32 & 7,67 & 9,33 & 10 & 3,67 & 5,67 & 7,33 & 2,33 & 4,33 & 6,33 \\
\hline C33 & 6,33 & 8,33 & 9,67 & 4,33 & 6,33 & 8,33 & 3 & 5 & 7 \\
\hline C34 & 7,67 & 9,33 & 10 & 3,67 & 5,67 & 7,33 & 3,67 & 5,67 & 7,67 \\
\hline C35 & 5,67 & 7,67 & 9 & 5 & 7 & 8,67 & 4,33 & 6,33 & 8 \\
\hline C41 & 6,33 & 8,33 & 9,67 & 3 & 5 & 7 & 2,67 & 4,33 & 6,33 \\
\hline C42 & 7,67 & 9,33 & 10 & 2,67 & 4,33 & 6,33 & 2,33 & 4,33 & 6,33 \\
\hline $\mathrm{C43}$ & 3,67 & 5,67 & 7,33 & 5,67 & 7,67 & 9,33 & 2,67 & 4,33 & 6,33 \\
\hline C44 & 6,33 & 8 & 9,33 & 4,33 & 6,33 & 8 & 2 & 3,67 & 5,67 \\
\hline C45 & 4 & 5,67 & 7,33 & 4 & 5,67 & 7,33 & 2 & 3,67 & 5,67 \\
\hline C51 & 8,33 & 9,67 & 10 & 4,67 & 6,33 & 7,67 & 1,67 & 3,67 & 5,67 \\
\hline C52 & 7,67 & 9,33 & 10 & 4,33 & 6,33 & 8 & 2,33 & 4,33 & 6,33 \\
\hline C53 & 5 & 7 & 8,33 & 4,33 & 6,33 & 8 & 2 & 3,67 & 5,67 \\
\hline C54 & 6,33 & 8 & 9 & 3 & 5 & 7 & 2,33 & 4,33 & 6,33 \\
\hline C55 & 5 & 7 & 9 & 4,33 & 6,33 & 8,33 & 1,33 & 3 & 5 \\
\hline \multirow[t]{3}{*}{ C56 } & 6,33 & 8,33 & 9,67 & 5 & 7 & 8,67 & 2,33 & 4,33 & 6,33 \\
\hline & \multicolumn{3}{|c|}{ 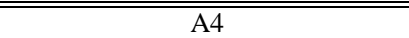 } & \multicolumn{3}{|c|}{ 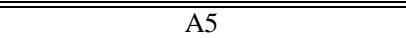 } & \multicolumn{3}{|c|}{ 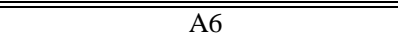 } \\
\hline & $\mathrm{t}_{\mathrm{l}}$ & $\mathrm{t}_{\mathrm{m}}$ & $t_{u}$ & $\mathrm{t}_{1}$ & $\mathrm{t}_{\mathrm{m}}$ & $\mathrm{t}_{\mathrm{u}}$ & $t_{1}$ & $\mathrm{t}_{\mathrm{m}}$ & $\mathrm{t}_{\mathrm{u}}$ \\
\hline C11 & 4,33 & 6 & 7,33 & 4,33 & 6,33 & 8 & 5,33 & 6,67 & 7,67 \\
\hline $\mathrm{C} 12$ & 7 & 9 & 10 & 7 & 9 & 10 & 7 & 9 & 10 \\
\hline C13 & 7 & 9 & 10 & 7 & 9 & 10 & 7 & 9 & 10 \\
\hline C14 & 5,67 & 7,67 & 9,33 & 5,67 & 7,67 & 9,33 & 5 & 7 & 9 \\
\hline $\mathrm{C} 15$ & 4,33 & 6,33 & 8,33 & 3,67 & 5,67 & 7,67 & 5,67 & 7,33 & 8,67 \\
\hline C21 & 3,67 & 5,67 & 7,67 & 5,67 & 7,67 & 9 & 2,33 & 3,33 & 4,67 \\
\hline C22 & 4 & 5,67 & 7,33 & 7 & 9 & 10 & 5 & 7 & 8,67 \\
\hline $\mathrm{C} 23$ & 3,33 & 5 & 6,67 & 6,33 & 8 & 9,33 & 7 & 8,67 & 9,67 \\
\hline C24 & 5 & 6,67 & 8 & 8,33 & 9,67 & 10 & 7,67 & 9,33 & 10 \\
\hline C25 & 1,33 & 3 & 5 & 2,33 & 4,33 & 6,33 & 1 & 2 & 3,67 \\
\hline C26 & 3 & 5 & 6,67 & 7 & 9 & 10 & 4,67 & 6,33 & 7,67 \\
\hline C27 & 5,67 & 7,67 & 9,33 & 6,33 & 8,33 & 9,67 & 3,67 & 5,67 & 7,33 \\
\hline C31 & 7 & 8,67 & 9,67 & 8,33 & 9,67 & 10 & 2 & 3,67 & 5,67 \\
\hline C32 & 4,33 & 6,33 & 8 & 7,67 & 9 & 9,67 & 3 & 5 & 7 \\
\hline C33 & 6,33 & 8 & 9 & 7,67 & 9,33 & 10 & 3,67 & 5,67 & 7,33 \\
\hline C34 & 5 & 7 & 8,67 & 6,33 & 8,33 & 9,67 & 3,67 & 5,67 & 7,33 \\
\hline C35 & 5 & 7 & 8,33 & 7 & 9 & 10 & 5 & 7 & 8,33 \\
\hline C41 & 4,67 & 6,33 & 7,67 & 7 & 9 & 10 & 3,33 & 5 & 7 \\
\hline C42 & 5 & 7 & 8,67 & 7 & 8,67 & 9,67 & 3,67 & 5,67 & 7,67 \\
\hline $\mathrm{C43}$ & 3,33 & 5 & 7 & 5,67 & 7,67 & 9,33 & 1,67 & 2,67 & 4,33 \\
\hline C44 & 4,67 & 6,33 & 7,67 & 7 & 8,67 & 9,67 & 2 & 3,67 & 5,67 \\
\hline $\mathrm{C45}$ & 3,33 & 5 & 6,67 & 6,33 & 8 & 9,33 & 2,67 & 4,33 & 6,33 \\
\hline C51 & 3 & 5 & 6,67 & 5,67 & 7,33 & 8,33 & 1,67 & 3,67 & 5,67 \\
\hline C52 & 5,67 & 7,67 & 9 & 7 & 8,33 & 9 & 1,33 & 3 & 5 \\
\hline C53 & 7,67 & 9,33 & 10 & 7,67 & 9,33 & 10 & 1,33 & 3 & 5 \\
\hline C54 & 4,33 & 6,33 & 8,33 & 7,67 & 9 & 9,67 & 2 & 3,67 & 5,67 \\
\hline C55 & 3,33 & 5 & 7 & 7 & 8,67 & 9,67 & 2 & 3,67 & 5,67 \\
\hline C56 & 3 & 5 & 7 & 5 & 7 & 8,67 & 1,33 & 3 & 5 \\
\hline
\end{tabular}

In Level 2, first, the normalized fuzzy decision matrix which was previously shown in equation (8) was constructed. After that, in Level 3, using the weighted normalized fuzzy values which were calculated using equation (10), the weighted normalized fuzzy decision matrix shown in equation (9) was constructed. Since these constructed matrices are too extensive, the calculation of these values and matrices showing them all collectively could not be given space here.

After Level 2 and 3 were complete, in Level 4 the positive and negative solution values of each alternative were 
determined with the help of equations (11) and (12); they are presented in Table 15 below.

Table 15. The Positive $\left(\mathrm{I}^{+}\right)$and Negative $\left(\mathrm{I}^{-}\right)$Ideal Solution Values of Alternatives

\begin{tabular}{|c|c|c|c|c|c|c|c|c|c|c|c|c|c|}
\hline \multicolumn{7}{|c|}{ Calculation of positive ideal solution values } & \multicolumn{7}{|c|}{ Calculation of negative ideal solution values } \\
\hline C11 & $\begin{array}{c}I_{\mathbf{1}}^{+} \\
0,001\end{array}$ & $\begin{array}{c}I_{2}^{+} \\
0,001\end{array}$ & $\begin{array}{c}\boldsymbol{I}_{\mathbf{3}}^{+} \\
0,002\end{array}$ & $\begin{array}{c}I_{4}^{+} \\
0,002\end{array}$ & $\begin{array}{c}\boldsymbol{I}_{\mathbf{5}}^{+} \\
0,002\end{array}$ & $\begin{array}{c}\boldsymbol{I}_{\mathbf{6}}^{+} \\
0,002\end{array}$ & C11 & $\begin{array}{c}\boldsymbol{I}_{\mathbf{1}}^{-} \\
0,003\end{array}$ & $\begin{array}{c}\boldsymbol{I}_{\mathbf{2}}^{-} \\
0,002\end{array}$ & $\begin{array}{c}\boldsymbol{I}_{\mathbf{3}}^{-} \\
0,002\end{array}$ & $\begin{array}{c}\boldsymbol{I}_{\mathbf{4}}^{-} \\
0,001\end{array}$ & $\begin{array}{c}I_{\mathbf{5}}^{-} \\
0,001\end{array}$ & $\begin{array}{c}\boldsymbol{I}_{\mathbf{6}}^{-} \\
0,001\end{array}$ \\
\hline C12 & 0 & 0 & 0 & 0 & 0 & 0 & C12 & 0,001 & 0,001 & 0,001 & 0,001 & 0,001 & 0,001 \\
\hline C13 & 0,001 & 0,001 & 0,001 & 0,001 & 0,001 & 0,001 & C13 & 0,001 & 0,001 & 0,001 & 0,001 & 0,001 & 0,001 \\
\hline C14 & 0,009 & 0,004 & 0,004 & 0,006 & 0,006 & 0,007 & C14 & 0,006 & 0,011 & 0,01 & 0,009 & 0,009 & 0,008 \\
\hline $\mathrm{C15}$ & 0,001 & 0,001 & 0,001 & 0,001 & 0,001 & 0,001 & C15 & 0,001 & 0,002 & 0,001 & 0,001 & 0,001 & 0,001 \\
\hline C21 & 0,012 & 0,007 & 0,012 & 0,009 & 0,005 & 0,014 & C21 & 0,006 & 0,01 & 0,006 & 0,009 & 0,013 & 0,004 \\
\hline $\mathrm{C} 22$ & 0,001 & 0,005 & 0,004 & 0,003 & 0,001 & 0,002 & $\mathrm{C} 22$ & 0,004 & 0,002 & 0,002 & 0,003 & 0,005 & 0,004 \\
\hline $\mathrm{C} 23$ & 0,004 & 0,008 & 0,008 & 0,009 & 0,004 & 0,003 & $\mathrm{C} 23$ & 0,008 & 0,005 & 0,005 & 0,004 & 0,008 & 0,009 \\
\hline $\mathrm{C24}$ & 0,002 & 0,008 & 0,007 & 0,006 & 0,002 & 0,002 & $\mathrm{C} 24$ & 0,009 & 0,004 & 0,005 & 0,005 & 0,009 & 0,009 \\
\hline $\mathrm{C} 25$ & 0,014 & 0,008 & 0,014 & 0,012 & 0,009 & 0,015 & $\mathrm{C} 25$ & 0,007 & 0,013 & 0,007 & 0,009 & 0,013 & 0,006 \\
\hline $\mathrm{C} 26$ & 0,002 & 0,007 & 0,009 & 0,007 & 0,002 & 0,005 & C26 & 0,009 & 0,004 & 0,003 & 0,005 & 0,009 & 0,006 \\
\hline C27 & 0,002 & 0,004 & 0,004 & 0,002 & 0,002 & 0,004 & C27 & 0,005 & 0,002 & 0,003 & 0,004 & 0,005 & 0,003 \\
\hline C31 & 0,008 & 0,01 & 0,014 & 0,004 & 0,002 & 0,014 & C31 & 0,012 & 0,009 & 0,006 & 0,015 & 0,017 & 0,006 \\
\hline C32 & 0,006 & 0,019 & 0,024 & 0,017 & 0,006 & 0,021 & C32 & 0,027 & 0,014 & 0,01 & 0,017 & 0,026 & 0,013 \\
\hline C33 & 0,013 & 0,022 & 0,028 & 0,013 & 0,008 & 0,025 & C33 & 0,029 & 0,02 & 0,014 & 0,026 & 0,033 & 0,016 \\
\hline C34 & 0,007 & 0,023 & 0,023 & 0,017 & 0,011 & 0,023 & C34 & 0,026 & 0,012 & 0,013 & 0,017 & 0,023 & 0,012 \\
\hline C35 & 0,004 & 0,005 & 0,006 & 0,005 & 0,003 & 0,005 & C35 & 0,005 & 0,004 & 0,004 & 0,004 & 0,007 & 0,004 \\
\hline C41 & 0,006 & 0,014 & 0,015 & 0,01 & 0,005 & 0,013 & C41 & 0,015 & 0,007 & 0,006 & 0,01 & 0,016 & 0,007 \\
\hline $\mathrm{C42}$ & 0,009 & 0,038 & 0,039 & 0,023 & 0,012 & 0,03 & C42 & 0,044 & 0,017 & 0,017 & 0,031 & 0,041 & 0,024 \\
\hline $\mathrm{C} 43$ & 0,034 & 0,019 & 0,043 & 0,038 & 0,019 & 0,055 & C43 & 0,035 & 0,051 & 0,026 & 0,031 & 0,051 & 0,014 \\
\hline C44 & 0,022 & 0,039 & 0,063 & 0,038 & 0,017 & 0,063 & C44 & 0,062 & 0,046 & 0,024 & 0,046 & 0,068 & 0,024 \\
\hline $\mathrm{C} 45$ & 0,033 & 0,033 & 0,048 & 0,038 & 0,016 & 0,043 & $\mathrm{C} 45$ & 0,033 & 0,033 & 0,019 & 0,028 & 0,05 & 0,024 \\
\hline C51 & 0,004 & 0,016 & 0,026 & 0,021 & 0,012 & 0,026 & C51 & 0,031 & 0,019 & 0,01 & 0,014 & 0,022 & 0,01 \\
\hline C52 & 0,008 & 0,024 & 0,035 & 0,017 & 0,012 & 0,042 & C52 & 0,046 & 0,03 & 0,02 & 0,037 & 0,04 & 0,014 \\
\hline C53 & 0,033 & 0,039 & 0,061 & 0,013 & 0,013 & 0,067 & C53 & 0,053 & 0,049 & 0,027 & 0,074 & 0,074 & 0,022 \\
\hline C54 & 0,004 & 0,01 & 0,011 & 0,007 & 0,002 & 0,012 & C54 & 0,011 & 0,007 & 0,006 & 0,009 & 0,013 & 0,005 \\
\hline C55 & 0,01 & 0,012 & 0,022 & 0,016 & 0,005 & 0,02 & C55 & 0,019 & 0,017 & 0,008 & 0,013 & 0,023 & 0,009 \\
\hline C56 & 0,018 & 0,028 & 0,05 & 0,044 & 0,028 & 0,06 & C56 & 0,062 & 0,051 & 0,03 & 0,036 & 0,051 & 0,021 \\
\hline
\end{tabular}

In Level 5 , the distances of each alternative from positive $\left(h_{i}^{+}\right)$and negative $\left(h_{i}^{-}\right)$ideal solutions were calculated using equations (14), (15), and (16). In the calculation of the distances of alternatives from the positive and negative ideal solutions the vertex method was used and the results obtained are presented in Table 16.

Table 16. The Distance of Alternatives from Positive $\left(\mathrm{I}^{+}\right)$and Negative $\left(\mathrm{I}^{-}\right)$Ideal Solution Values

\begin{tabular}{ccc}
\hline Presidents & $h_{i}^{+}$ & $h_{i}^{-}$ \\
\hline A1 & 0,269 & 0,570 \\
A2 & 0,403 & 0,443 \\
A3 & 0,572 & 0,286 \\
A4 & 0,380 & 0,460 \\
A5 & 0,208 & 0,630 \\
A6 & 0,575 & 0,276 \\
\hline
\end{tabular}

In Level 6 , the $h_{i}^{+}$and $h_{i}^{-}$values shown in Table 16 were used in equation (17), and closeness degrees pertaining to the alternatives $\left(\mathrm{CD}_{\mathrm{i}}\right)$ were calculated; they are presented in Table 17.

Table 17. The Closeness Degrees of Alternatives

\begin{tabular}{ccc}
\hline Presidents & $\mathrm{CD}_{\mathrm{i}}$ & Ranking \\
\hline A1(R.Tayyip Erdogan) & 0,679 & 2 \\
A2 (Abdullah Gul) & 0,523 & 4 \\
A3 (A.Necdet Sezer) & 0,333 & 5 \\
A4(Süleyman Demirel) & 0,547 & 3 \\
A5 (Turgut Ozal) & 0,751 & 1 \\
A6(Kenan Evren) & 0,324 & 6 \\
\hline
\end{tabular}

In the ranking performed with respect to the closeness degrees of the alternatives, Turgut Ozal ranked first with 0.751 points, followed by R. Tayyip Erdogan with 0.679, Suleyman Demirel with 0.547, Abdullah Gul with 0.523 and A. Necdet Sezer with 0.333 points. With 0.324 points Kenan Evren ranked last in respect to closeness degree. According to these results, from among the selected presidents Turgut Ozal, who served between 1989 and 1993, turned out to be the most charismatic leader.

\section{Conclusion}

The literature is rich with studies of the concept of leadership, which can be defined as gathering a group of people around certain goals, and mobilizing and directing these people in the way of realizing these goals. In approaches 
analyzing this concept, first, the personal traits of the leader were tackled, then emphasis was given to the leader's behaviors, while in recent periods these approaches were expanded to include situations in which the leader's behaviors, and their followers' traits, are elaborated. These approaches, and the studies carried out within the scope of these approaches, have resulted in literature about leadership that is very wide, and have shown that there are many factors involved in determining leadership type or the nature of a leader. Although there are many studies in such fields as management, politics, philosophy, psychology, sociology, social psychology and communication which deal with subjects such as leadership, leadership types and leadership approaches, the number of studies in which quantitative decision-making methods and techniques are used in relation to these topics is very limited. The fundamental reasons restricting these types of studies are that traditional decision-making methods and techniques obligate the use of quantitative data, and these techniques are based on Aristotelian logic. The entry of fuzzy logic in the literature has expanded the fields of applicability of traditional decision-making methods and techniques. Fuzzy logic allows evaluations and judgments that people in decision-making positions made and preferred to state verbally to be included in the solution process, by quantifying them with the help of fuzzy numbers. Such a development has made it possible to use the methods and techniques in question in difficult-to-measure subjects such as leadership.

In this context, a new approach was adopted in this study, by associating quantitative decision-making methods and techniques with the topic of charismatic leadership. Six presidents who served the Republic of Turkey as Head of State were evaluated with respect to charismatic leadership using the AHP and Fuzzy TOPSIS methods alongside one another. Qualities that determine charismatic leadership were determined based on the literature; these qualities were then given a final shape after interviews conducted with experts in the area; their weights were calculated using the AHP method; and finally it was determined which president was the most charismatic utilizing the Fuzzy TOPSIS method.

The results obtained with our application of the Analytic Hierarchy Process method show that the most important criteria for charismatic leadership is "communication". The communication criteria were followed by the managerial, mental, personal and demographic main criteria, respectively. The fact that communication is the most important main criteria for charismatic leadership points to the fact that the sub-criteria of the leader having effective communication with their followers, the ability to persuade them in the way of their goals, the ability to take risks for the benefit of followers when necessary, being a creative person and open to changes to support followers' development, are also important from the perspective of charismatic leadership. In addition to this, the results also emphasize that charismatic leaders should be reliable, service oriented, sensitive to followers' needs, able to think analytically, able to share a common vision with their followers, able to draw lessons from mistakes, highly self-confident, able to show empathy towards followers and determined individuals. Likewise, the results obtained from the AHP show that the education sub-criterion from the demographic criteria is perceived as relatively more important than the other sub-criteria such as physical appearance, marital status, gender and age.

In the next stage, the main and sub criteria weights that were calculated using the AHP method were used in the Fuzzy TOPSIS method, and the six selected presidents were graded with respect to charismatic leadership. The results obtained from the Fuzzy TOPSIS method turned out to be in line with the general opinion held before the study started, that when compared to other presidents, Turgut Ozal, who served as the $8^{\text {th }}$ President of the Republic of Turkey in the period 1989-1993, was determined to be the most charismatic leader. Turgut Ozal was followed by Recep Tayyip Erdogan, Suleyman Demirel, Abdullah Gul, Ahmet Necdet Sezer and Kenan Evren, respectively.

\section{Recommendations}

Although many studies have been conducted on the concepts of the leader, leadership approaches and charismatic leadership, that there is limited number of studies tackling these concepts and MCDM methods together is a deficiency on the part of management organization fields. This study attempts to address this deficiency. The results obtained from this study show that MCDM methods and techniques, among which are the AHP and Fuzzy TOPSIS methods, can be applied in subjects such as the evaluation of leaders and the determination of leadership qualities that are considered to mostly fall into the field of management science. In addition, in these types of problem structures, picking up decision points that have relatively similar features and qualities to one another makes it difficult for decision makers to determine the most effective one. Using MCDM methods that aim to reach the most effective decision point based on quantitative data can help to overcome this problem. By employing various methods and techniques traditionally considered to fall under the scope of other fields, researchers in the field of management science can affect interdisciplinary interaction in a positive way and can also help to introduce different and more creative studies to the literature. From this perspective, conducting different studies employing the MCDM method and techniques other than AHP and Fuzzy TOPSIS in the field of management science would enhance diversity in the literature. Likewise, determining which type of leadership style successful leaders mostly exhibit by utilizing these methods and techniques would enhance the existing body of knowledge and give way to new studies. 


\section{References}

Anand, G., \& Kodali, R. (2007). Evaluation of New Product Alternatives Using A Multi-Attribute Decision Model. ICFAI Journal of Operations Management. 6(4), 27-49, Accession number: 27615948.

Antonakis, J. (2006). Leadership: What is it and how it is implicated in strategic change. International Journal of Management Cases, 8(4), 4-20, https://serval.unil.ch/resource/serval:BIB_DCDF27DC615B.P001/REF

Ardakani, S. S., Nejatian, M., Farhangnejad, M. A., \& Nejati, M. (2015). A fuzzy approach to service quality diagnosis. Marketing Intelligence \& Planning, 33(1), 103-119, http://dx.doi.org/10.1108/MIP-02-2013-0035

Arklan, U. (2006). Siyasal Liderlikte Karizma Olgusu: Recep Tayip Erdogan Örneğinde Teorik ve Uygulamalı bir çalısma. Selcuk University Social Sciences Institute Journal, 16, 45-65.

Aslan, S. (2009). The relation of charismatic leadership and organizational citizenship behavior: The role of 'tenure' and 'salary' variables. Uluslararası İnsan Bilimleri Dergisi, 6(1), 256-275.

Atan, M., Atan, S., \& Altın, K. (2008). The Use of Analytic Hierarchy in Human Resource Recruitment and A Proposal for Software. Gazi Üniversitesi IIBF Dergisi, 10(3), 143-162, ISSN: 1302-2024, Accession number: 50282621.

Bailey, S. S. (1988). The relationship between leadership styles of high school principals and school climate as perceived by teachers. [CD-ROM]. Abstract from: ProQuest File: Dissertation Abstracts International Item: 50/09.

Bass, B. M. (1985). Leadership and performance beyond expectations. Free Press; Collier Macmillan. ISBN, 0029018102.

Bass, B. M., \& Stogdill, R. M. (1990). Bass \& Stogdill's handbook of leadership: Theory, research, and managerial applications. Simon and Schuster. ISBN, 0029015006

Bass, B. M., \& Stogdill, R. M. (1990). Bass \& Stogdill's handbook of leadership: Theory, research, and managerial applications. Simon and Schuster. http://books.simonandschuster.com, ISBN: 9780743215527.

Bendix, R. (1967). Reflections on charismatic leadership. Asian Survey, 7(6), 341-352.

Bennis, W. G. (1959). Leadership theory and administrative behavior: The problem of authority. Administrative science quarterly, 4(3), 259-301, http://dx.doi.org/10.2307/2390911

Burns, J. M. (1978). Leadership. New York: Harper \& Row. ISBN: 9780061965579 ISBN 10: 006196557X

Can, H., Aşan, Ö., \& Aydın, E. M. (2006). Örgütsel Davranış, Arıkan Basın Yayın, İstanbul.

Chen, C. T. (2000). Extensions of the TOPSIS forgroupdecision-makingunderfuzzyenvironment. Fuzzy Sets and Systems, 114, 1-9. http://dx.doi.org/10.1016/S 0165-0114(97)00377-1

Conger, J. A., \& Kanungo, R. N. (1987). Toward a behavioral theory of charismatic leadership in organizational settings. Academy of management review, 12(4), 637-647. http://dx.doi.org/10.5465/AMR.1987.4306715

Conger, J. A., \& Kanungo, R. N. (1994). Charismatic leadership in organizations: Perceived behavioral attributes and their measurement. Journal of organizational behavior, 15(5), 439-452. http://dx.doi.org/10.1002/job.4030150508.

Conger, J. A., \& Kanungo, R. N. (1998). Charismatic leadership in organizations. Sage Publications. ISBN, 0761916334.

Conger, J. A., Kanungo, R. N., \& Menon, S. T. (2000). Charismatic leadership and follower effects. Journal of organizational behavior, 21(7), 747-767. http://dx.doi.org/10.1002/1099-1379(200011)21:7<747:AID-JOB46>3.0.CO;2-J

Conger, J. A., Kanungo, R. N., \& Menon, S. T. (2000). Charismatic leadership and follower effects. Journal of Organizational Behavior, 21, 747-767, ISSN: 0894-3796, Accession number: 13620123.

Demircioglu, E. C. (2015). Evaluation of Charismatic Leadership from Management Perspective. Uluslararast Akademik Yönetim Bilimleri Dergisi, 1(1), 52-69.

Ecer, F. (2006). Bulanık Ortamlarda Grup Kararı Vermeye Yardımcı Bir Yöntem: Fuzzy TOPSIS ve Bir Uygulama. Dokuz Eylul University Faculty of Economics and Administrative Sciences Journal, 7(2), 77-96.

Eraslan, E., \& Tansel, Y. (2011). A multi-criteria approach for determination of investment regions: Turkish case. Industrial Management \& Data Systems, 111(6), 890-909. http://dx.doi.org/10.1108/02635571111144964

Eraslan, L. (2004). Liderlik olgusunun tarihsel evrimi, temel kavramlar ve yeni liderlik paradigmasının analizi. Milli Eğitim Dergisi, 162, 1-14.

Erçetin, Ş. (1998). Lider sarmalında vizyon. Nobel Yayın Dağıtım, Ankara, ISBN 9755911650. 
Eren, E. (2012). Örgütsel davranış ve yönetim psikolojisi. Beta Basım Yayım Dağıtım, İstanbul.

Erginel, N., Cakmak, T., \& Sentürk, S. (2010). Determining The Preference Of GSM Operators In Turkey With Fuzzy TOPSIS After Mobile Number Portability System Application, Anadolu University Journal Of Science And Technology-A, Applied Sciences and Engineering, 11 (2), 81-93, ISSN: 1302-3160, Accession number: 65209845.

Erol, I., Cakar, N., Erel, D., \& Sari, N. (2009). Sustainability in the Turkish Retailing Industry. Sustainable Development, 17, 49-67. http://dx.doi.org/10.1002/sd.369

Erpolat, S., \& Cinemre, N. (2006). Analitik Hiyerarşi Yöntemi’yle İş Sektörü Seçimi. Öneri, 7(25), 231-241, ISSN: 1300- 0845, Accession number: 91292

Ertan-Kantos, Z. (2011). Leadership in Organization Metaphors: A Conceptual Analysis. Journal of Educational Sciences Research, 1 (1), 135-158.

Gill, R. (2011). Theory and practice of leadership. Sage, ISBN 10: 1849200246

Gokdalay, M. H., \& Evren, G. (2009). Fuzzy multicriteria decision making approach for airport performance analysis. itüdergisi/d mühendislik, 8 (6), 157-168, ISSN: 1303-703X, Accession number: 47363244.

Goksu, A., \& Gungor, I. (2008). Fuzzy Analytic Hierarchy Process and Its Application of University Preference Ranking. Suleyman Demirel University, The Journal of Faculty of Economics and Administrative Sciences, 13(3), $1-26$.

Horner, M. (1997). Leadership theory: past, presentandfuture. Team Performance Management: An International Journal, 3(4), 270-287. http://dx.doi.org/10.1108/13527599710195402

House, R. J. (1977). A 1976 Theory of charismaticleadership. In J.G. Hunt\&L.L.Larson (Eds). ERIC Number: ED133827

Howell, J. M., \& Avolio, B. J. (1992). The ethics of charismatic leadership: submission or liberation?.TheExecutive, 6(2), 43-54, http://dx.doi.org/10.5465/AME.1992.4274395

Kabra, G., \& Ramesh, A. (2015). Analyzing driver sand barriers of coordination in humanitarian supply chain management under fuzzy environment. Benchmarking: An International Journal, 22(4), 559-587. http://dx.doi.org/10.1108/BIJ-05-2014-0041

Kahraman, C., Ates, N. Y., Cevik, S., Gulbay, M., \& Erdogan, S. A. (2007). Hierarchical fuzzy TOPSIS model for selection among logistics information technologies. Journal of Enterprise Information Management, 20(2), 143-168. http://dx.doi.org/10.1108/17410390710725742

Kapar, K. (2013). Supplier Selection within the Process of Analytical Hierarchy in a Business, Dokuz Eylül University Faculty of Economics and Administrative Sciences Journal, 28(1), 197-231, ISSN: 1302-504X, Accession number: 180896.

Katz, D., \& Kahn, R. L. (1978). The social psychology of organizations. John Wiley\&Sons: New York, ISBN: 978-0-471-02355-5.

Koçel, T. (2011). İşletme Yöneticiliği. Beta Basım Yayım Dă̆ııım AŞ., İstanbul.

Kozleme, O. (2013). Leadership, Political Authority Types and Charisma. Toplum Bilimleri Dergisi, 7(13), 239-250.

Kumru, M., \& Kumru, P. Y. (2014). Analytic hierarchy process application in selecting the mode of transport for a logistics company, J. Adv. Transp. 48, 974-999, http://dx.doi.org/10.1002/atr.1240

Lewin, K. (1944). A research approach to leadership problems. The Journal of Educational Sociology, 17 (7), 392-398. http://dx.doi.org/10.2307/2262546

Lombardi, P., Sokolnikova, T., Suslov, K., Voropai, N., \& Styczynski, Z. A. (2016). Isolated power system in Russia: A chance for renewable energies?. Renewable Energy, 90, 532-541, http://dx.doi.org/10.1016/j.renene.2016.01.016

Mahdevari, S., \& Shahriar, K. E. (2014). Human health and safety risks management in under ground coalmines using fuzzy TOPSIS, Science of the Total Environment, 488-489, 85-99. http://dx.doi.org/10.1016/j.scitotenv.2014.04.076

McGregor, D. (1952). Leadership and the Conditions of Organizational Effectiveness. Public Health Reports (1896-1970), 67(1), 42-46. http://dx.doi.org/ 10.2307/4587978

Murphy, A. J. (1941). A Study of the Leadership Process. American Sociological Review, 6(5), 674-687, ISSN: 00031224 , Accession number: 12581086.

Murphy, E. G. (1907). The Task of the Leader: A Discussion of Some of the Conditions of Public Leadership in Our Southern States. The Sewanee Review, 15(1), 1-30. 
Nanus, B., \& Bennis, W. (1985). Leaders: The strategies for taking charge. Harper and Row, New York, ISBN: 0060913363.

Onut, S., \& Soner, S. (2008). Trans-shipment site selection using the AHP and TOPSIS approaches under fuzzy environment. Waste Management, 28, 1552-1559. http://dx.doi.org/10.1016/j.wasman.2007.05.019

Qu, Q., Chen, K. Y., Wei, Y. M., Liu, Y., Tsai, S. B., \& Dong, W. (2015). Using Hybrid Model to Evaluate Performance of Innovation and Technology Professionals in Marine Logistics Industry, Mathematical Problems in Engineering, Volume 2015, Article ID 361275, 8 pages. http://dx.doi.org/10.1155/2015/361275

Retchless, T., Golden, B., \& Wasil, E. (2007). Ranking US Army Generals of the 20th Century: A Group Decision-Making Application of the Analytic Hierarchy Process. Interfaces, 37(2), 163-175, ISSN: 0092-2102, EISSN: 1526-551X.

Rost, J. C. (1991). Leadership for the twenty-first century. Praeger: New York, ISBN, 027594610X.

Rost, J. C. (1993). Leadership for the twenty-first century. Greenwood Publishing Group, Portsmouth, ISBN: 027594610X.

Rowold, J., \& Laukamp, L. (2009). Charismatic leadership and objective performance indicators. Applied Psychology, 58(4), 602-621. http://dx.doi.org/10.1111/j.1464-0597.2008.00365.x

Saaty, T. L. (1986). Axiomatic Foundation of the Analytic Hierarchy Process", Management Science. 32(7), 841-855. http://dx.doi.org/10.1287/mnsc.32.7.841

Saaty, T. L. (1990). How to make a decision: The Analytic Hierarchy Process. European Journal of Operational Research, 48, 9-26. http://dx.doi.org/10.1016/0377-2217(90)90057-I

Saaty, T. L. (1994). How to make a decision: theanalytichierarchy process. Interfaces, 24(6), 19-43. http://dx.doi.org/10.1287/inte.24.6.19

Saaty, T. L. (2008). Decision making with the analytichierarchy process. Int. J. Services Sciences, 1(1), 83-98. http://dx.doi.org/10.1504/IJSSCI.2008.017590

Saaty, T. L., \& Zoffer, H. J. (2012). A New Approach To The Middle East Conflict: The Analytic Hierarchy Process. Jornal of Multi-Criteria Decision Analysis, 19, 201-225. http://dx.doi.org/10.1002/mcda.1470

Sabuncuoğlu, Z., \& Tüz, M. (2008). Örgütsel Psikoloji, Furkan Ofset, Bursa.

Sari, K. (2013). Selection of RFID solution provider. Kybernetes, 42(3), 448-465. http://dx.doi.org/10.1108/03684921311323680

Sarode, A. D., \& Sunnapwar, P. M. (2010). IMPROVING EFFECTIVENESS OF SUPPLY CHAIN BY SELECTING AN APPROPRIATE SUPPLIER: AN ANALYTIC HIERARCHY PROCESS APPROACH, Journal of Advanced Manufacturing Systems, 9(2), 129-144. http://dx.doi.org/10.1142/S0219686710001855

Sashkin, M. (1988). The Visionary Principal: School Leadership for the Next Century. Education and Urban Society, 20(3), 239-49.

Schoenfeld, B. N. (1948). The psychological characteristics of leadership. Social Forces, 391-396. http://dx.doi.org/10.2307/2571872

Selznick, P. (2011). Leadership in administration: A sociological interpretation. Quid Pro Books. ISBN: 0520049942.

Shamir, B. (1995). Social distance and charisma: Theoretical notes and an exploratory study. The Leadership Quarterly, 6(1), 19-47. http://dx.doi.org/10.1016/1048-9843(95)90003-9

Shapira, A., \& Goldenberg, M. (2005). AHP-Based Equipment Selection Model for Construction Projects. Journal $\begin{array}{lllll}\text { of Construction, } \quad \text { Engineering } \quad \& \quad \text { Management, } & 131(12), & 1263-1273 .\end{array}$ http://dx.doi.org/10.1061/(ASCE)0733-9364(2005)131:12(1263)

Şişman, M. (2014). Öğretim Liderliği. Pegem Akademi, Ankara. 5. Baskı.

Sosik, J. J. (2005). The role of personal values in the charismatic leadership of corporate managers: A model and preliminary field study. The Leadership Quarterly, 16(2), 221-244. http://dx.doi.org/10.1016/j.leaqua.2005.01.002

Soylu, Y., Tabak, A., \& Polat, M. (2007). Determining The Perceptions of Defence Industry Companies' Mid-Level Managers Wroking in Ankara on Leadership Components: A Study With Analytical Hierarchy Process (AHP), ZKÜ Sosyal Bilimler Dergisi, 3(5), 179-191, ISSN: 1303-9245, Accession number: 90185.

Sun, C. C., \& Lin, G. T. R. (2009). Using fuzzy TOPSIS method for evaluating the competitive advantages of shopping websites. Expert Systems with Applications, 36, 11764-11771. http://dx.doi.org/10.1016/j.eswa.2009.04.017 
Tayyar, N. (2012). Fuzzy AHP And Fuzzy TOPSIS Approach To Pet Bottle Supplier Selection, Suleyman Demirel University, The Journal of Faculty of Economics and Administrative Sciences, 17(3), 351-371, ISSN: 1301-0603, Accession number: 86970751.

Trillas, E. (2011). Lotfi A.Zadeh: On the man and his work, Scientia Iranica, 18(3), 574-579. http://dx.doi.org/10.1016/j.scient.2011.05.001

Tsita, K. G., \& Pilavachi, P. A. (2012). Evaluation of alternative fuels for the Greek road transport sector using the analytic hierarchy proces., Energy Policy, 48, 677-686, Accession number: 163919.

Tucker, R. C. (1968). Thetheory of charismaticleadership. Daedalus, 731-756. ISSN: 00115266

Ünal, Ö. F., \& İbicioğlu, H. (2014). Competency Based Human Resource Manager Selection By Analytic Hierarchy Process. Atatürk Üniversitesi İktisadi ve İdari Bilimler Dergisi, 28(4), 54-78.

Uysal, F., \& Tosun, O. (2012). Fuzzy TOPSIS-based computerized maintenance management system selection. $\begin{array}{llll}\text { Journal of Manufacturing Technology } & \text { Management, } & \text { 23(2), }\end{array}$ http://dx.doi.org/10.1108/17410381211202205

Van Seters, D. A., \& Field, R. H. (1990). The evolution of leadership theory. Journal of organizational change management, 3(3), 29-45, ISSN: 0953-4814, Accession number: 6552392.

Vidal, L. A., Marle, F., \& Bocquet, J. C. (2011). Using a Delphi process and the Analytic Hierarchy Process (AHP) to evaluate the complexity of projects. Expert Systems with Applications, 38, 5388-5405. http://dx.doi.org/10.1016/j.eswa.2010.10.016

Weber, M. (1947). The theory of social and economic organization. Simon and Schuster: New York.

Wren, J. T. (1995). The leader's companion. Insights on Leadership through the Ages. The Free Press, New York, ISBN: 0028740912.

Yıldırım, F., \& Önder, E. (2014). Çok Kriterli Karar Verme Yöntemleri. Dora Yayınları, Bursa, ISBN: 978-605-9929-44-8.

Yılmaz, M. (2010). The Analytic Hierarchy Process (AHP) and an Application: The Selection of a Library Director as a Leader. Türk Kütüphaneciliği, 24(2), 206-234.

Yong, D. (2006). Plantlocationselectionbased on fuzzy TOPSIS. Int.J.Adv.MAnuf.Technol., 28, 839-844. http://dx.doi.org/10.1007/s00170-004-2436-5

Yukl, G. (2010). Leadership in organisations. Prentice Hall, NJ., ISBN 10: 0132771861.

Zaleznik, A. (1990). The managerial mystique: Restoring leadership in business. Harper Collins, New York, ISBN : 0060917083. http://www.tccb.gov.tr/cumhurbaskanlarimiz/

\section{Copyrights}

Copyright for this article is retained by the author(s), with first publication rights granted to the journal.

This is an open-access article distributed under the terms and conditions of the Creative Commons Attribution license (http://creativecommons.org/licenses/by/3.0/). 